\title{
Branchial Rickettsiales-like infection associated with a mass mortality of sea scallop Pecten maximus
}

\author{
G. Le Gall, D. Chagot, E. Mialhe, H. Grizel \\ Laboratoire de pathologie et de génétique des Invertébrés marins, IFREMER, BP 133, F-17390 La Tremblade, France
}

ABSTRACT A branchial infection of Pecten maximus is histologically and ultrastructurally described. Gill epithelial cells were heavily infected with colonies of procaryotes, believed to belong to the Rickettsiales

In March 1987, a mass mortality (ca $40 \%$ ) of Pecten maximus from St Brieuc, N Brittany, France, was reported. Collections were made at this site in order to conduct an anatomopathological study, which revealed a procaryotic infection of gill endothelial cells.

Materials and Methods. Adult and juvenile scallops were collected by dredging at St Brieuc. Tissues were fixed either in Carson's fixative for light microscopy or in glutaraldehyde $1.25 \%$ /paraformaldehyde $2 \%$ in 0.1 $M$ sodium cacodylate/HCl buffer $\mathrm{pH} 7.4$, followed by $1 \%$ osmium tetraoxide in the same buffer, for transmission electron microscopy (TEM). Osmolarity was raised to 1100 mosm with sucrose (primary fixative) or with sodium chloride (secondary fixative). For light microscopy, samples of gills, digestive gland, mantle, kidney and muscle of a first set of 25 individuals were processed and embedded in paraffin; $3 \mu \mathrm{m}$ sections were stained with hematoxylin and eosin. A second set of 50 individuals was treated as above except that only gills and digestive gland were examined.

For TEM, gill tissues were prepared using an automatic processor and embedded in LX 112. Sections (60 to $90 \mathrm{~nm}$ ) were contrasted with lead citrate and aqueous uranyl acetate by means of the LKB Ultrostainer. Grids were examined with a Jeol 1200 CX electron microscope.

Results. Light microscopy revealed heavy infection of endothelial cells underlying gill filaments by intracytoplasmic colonies containing basophilic procaryote cells. Colonies varied in size, from small, containing only a few procaryotes (Fig. 1), to large, which obstructed the blood spaces (Fig. 2). No colonies were seen in the digestive epithelia. Two types of colonies could be distinguished in the infected branchial tissue: Type I, containing globular cells with a moderate basophilic character; and Type II, composed of intensely basophilic bacillary cells.

In some cases, the microorganisms were not confined to host cells but were encountered free, possibly accounting for spread of the infection. Every scallop examined was affected but no hemocytic infiltration was observed. Unlike Gulka's observations (Gulka et al. 1983) the adductor muscle did not show any sign of myodegeneration. In addition to these first results, an ongoing epidemiology study indicated: (1) The rate of infection among scallops from the Bay of St Brieuc was almost $100 \%$ for all ages examined (18 mo, 2 and $3 \mathrm{yr}$ old). (2) The infection was intense - an average number of 40 colonies could be counted on a section consisting of 4 transversal branchial pieces of equal surface.

At the ultrastructural level, the colonies of microorganisms were enclosed in a parasitophorus vacuole having a unit type membrane (Fig. 3).

Type I colonies were composed of tightly packed globular cells (up to $1.5 \mu \mathrm{m}$ in length, $1 \mu \mathrm{m}$ in diameter) with a reduced periplasmic space and a smooth outer membrane (Fig. 4). A central network of DNA fibrills appeared clearly in the protoplasm.

Type II colonies contained small rods averaging 1 to $2.5 \mu \mathrm{m}$ length and ca $0.5 \mu \mathrm{m}$ in diameter (Fig. 5). A wide periplasmic space separated the plasma membrane and the cell wall, which consisted of a single infolded unit membrane. In the cytoplasm, dense ribosomes were homogeneously scattered and the nucleoid structures were discrete. Some micrographs suggest that microorganisms divide by transverse binary fission (Fig. 5).

Cytopathological effects in infected host cells lead to complete destruction of the cytoplasm in which only vacuoles and subcellular unidentifiable fragments 

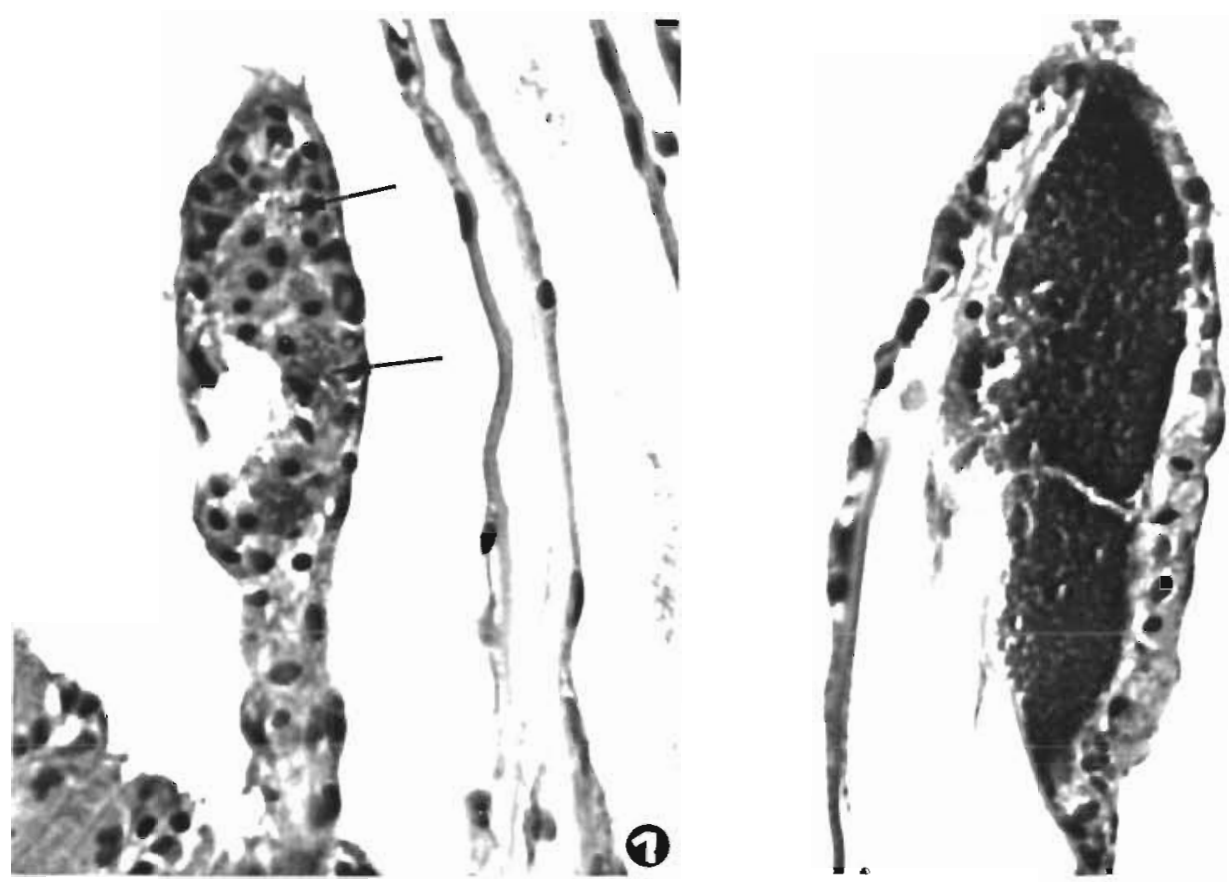

\section{$\Theta$}

Figs. 1 and 2. Pecten maximus. Light micrographs of gill tissues. Fig. 1. Small colonies of a few procaryotes (arrows). Fig. 2. Large colonies $(\times 400)$

remain. The adjacent epithelial cells retain a normal apearance (despite mechanical compression) (Fig. 3).

Discussion. The ultrastructural characteristics of the procaryotes reported in this study, and the absence of a complex developmental cycle, suggest that they belong to the Rickettsiales. Their intravacuolar growth is similar to the development of the genera Wolbachia from insects and Coxiella from vertebrates (Moulder 1974)

The 2 types of colonies could reflect different maturation steps; Type I may be young colonies in which the procaryote actively multiplies resulting in a packed appearance and a prominent nucleoid and Type II colonies may be older, with a slower multiplication rate producing bacillary-shaped microorganisms. In our opinion, the rippled appearance of the cell wall in older forms is not due to fixation or processing, because the 2 types of colonies may be encountered near one another on the same ultrathin section. Moreover, osmotic pressure was carfully adjusted in TEM fixatives. We feel it is more likely that Type II microorganisms are physiologically degenerating. These morphological data are insufficient to establish relationships with large and small forms of Coxiella (Weiss 1982).

Several Rickettsiales-like infections have been reported in marine invertebrates (Buchanan 1978, Otto et al. 1979, Meyers 1981, Joly 1982, Comps 1983, Gulka et al. 1983, Morrison \& Shum 1983, Elston \& Peacock 1984, Elston 1986, Mial.he et al. 1987), some suggesting an association with mortalities (Gulka et al. 1983). To date, whether or not these infections cause significant damage to the host is still a matter of discussion (Elston 1986). The intensity of infection supports the hypothesis that gill function is compromised. However, study of experimental infections is needed to demonstrate pathogenicity. Isolation and purification of the infectious agent would also allow the application of techniques such as protein electrophoresis, analysis of genomic content, and antigenic structure determination. These techniques would more accurately establish the precise taxonomic status of this procaryote.

Acknowlegements. The authors are most grateful to J. C. Dao, (IFREMER), C. Halary, Y. Royer (CEECN) and G. Bonhomme (IFREMER, LPGIM) for their assistance in this work.

\section{LITERATURE CITED}

Buchanan, J. S. (1978). Cytological studies on a new species of Rickettsia found in association with a phage in the digestive gland of the marine bivalve mollusc Tellina tenuis (da Costa) J. Fish Dis. 1: 27-43

Comps, M. (1983). Recherches histologiques et cytologiques sur les infections intracellulaires des mollusques bivalves marins. These Doctorat d Etat, USTL. Montpellier

Elston, R. A., Peacock, M. G. (1984). A Rickettsiales-like infection in the Pacific razor clam Siliqua patula. J. Invertebr. Pathol. 44: 84-96

Elston, R. A. (1986). Occurence of branchial Rickettsiales-like infections in two bivalve molluscs, Tapes japonica and 

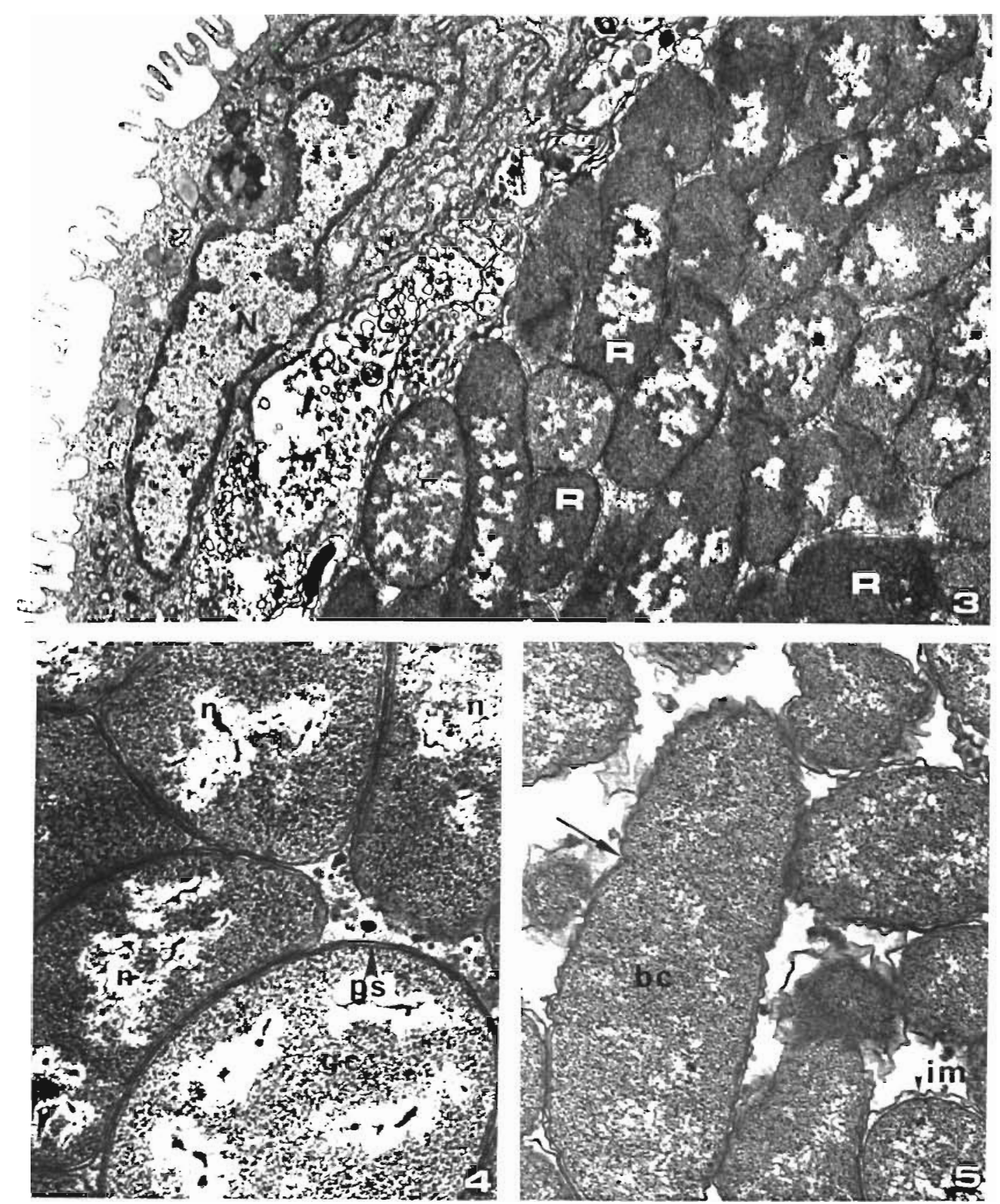

Figs. 3 to 5. Pecten maximus. Transmission electron micrographs of gill tissues. Fig. 3. Intracytoplasmic procaryotic colony R: rickettsia; V: vacuolization; $N$ : normal-appearing epithelial cell nucleus. ( $\times 15000)$. Fig. 4 . Type I colony. gc: globular cell; ps: periplasmic space; $n$ : nucleoid. $(\times 40000)$. Fig. 5 . Type II colony. bc: bacillary cell; im: infolded unit membrane. Arrow: suggested point of division by binary fission $(\times 40000)$

Patinopecten yessoensis with comments on their significance. J. Fish. Dis. 9: 69-71

Gulka, G., Chang, P. W., Marti, K. A. (1983). Procaryotic infection associated with the mass mortality of the sea scallop Placopecten magellanicus. J. Fish Dis. 6: 355-364

Joly, J. P. (1982). Contribution à la biologie de la palourde Ruditapes decussatus L. Thèse Doctorat 3 ème cycle, Univ. Paris VI
Meyers, T R. (1981). Endemic diseases of cultured shellfish of Long Island, New York: adult and juvenile American oysters (Crassostrea virginica) and hard clams (Mercenaria mercenaria). Aquaculture 22: 305-330

Mialhe, E., Chagot, D., Boulo, V., Comps, M., Ruano, F., Grizel, H. (1987). An infection of Ruditapes decussatus (Bivalvia) by Rickettsia. Aquaculture 67: 258-259

Morrison, C., Shu, G. (1983). Rickettsias in the kidney of the 
bay scallop, Argopecten irradians (Lawarck): J. Fish Dis. 6: $537-541$

Moulder, J. W (1974). The Rickettsiae. In: Buchanan, R. E., Gibbons, N. E. (eds.) Bergey's manual of determinative bacteriology, 8th edn. Williams and Wilkins Company, Baltimore, p. 882-914

Otto, S. V., Harshbarger, J. C., Chang, S. C. (1979). Status of selected unicellular eucaryote pathogens and prevalence and histophathology of inclusions containing obligate procaryote parasites in commercial bivalve molluscs from Maryland estuaries. Haliotis 8: 285-295

Weiss, E. (1982). The biology of Rickettsiae. Ann. Rev. Microbiol. 36 : $345-370$

Responsible Subject Editor: Dr A. K. Sparks: accepted for printing on May 6, 1988 